\title{
Effect of Debt Default, Disclosure, and Financial Distress on the Receiving of Going Concern Audit Opinions
}

\author{
Ari Tihar ${ }^{1 *}$; Indriani Puspita Sari²; Bambang Leo Handoko ${ }^{3}$ \\ ${ }^{1,2,3}$ Accounting Department, Faculty of Economics and Communication, Bina Nusantara University \\ Jl. K. H. Syahdan No. 9, Palmerah, Jakarta 11480, Indonesia \\ 1aritihar06@gmail.com1; ${ }^{2}$ indrianipuspita28@gmail.com; ${ }^{3}$ bambang_lh@yahoo.co.id
}

Received: $18^{\text {th }}$ February 2021/ Revised: $07^{\text {th }}$ April 2021/ Accepted: $12^{\text {th }}$ April 2021

\begin{abstract}
How to Cite: Tihar, A., Sari, I. P., \& Handoko, B. L. (2021). Effect of debt default, disclosure, and financial distress on the receiving of going concern audit opinions. The Winners, 22(2), 155-161.

https://doi.org/10.21512/tw.v22i2.7072
\end{abstract}

\begin{abstract}
The research aimed to investigate the impact of debt default, disclosure, and financial distress on the acknowledgment of going concern audit opinion in manufacturing companies. The research applied a quantitative type of data complimented with secondary data retrieved from the official website of Indonesia Stock Exchange. Data obtained from purposive sampling method with 108 samples, consisting of 36 manufacturing companies listed on the Indonesia Stock Exchange in 2016-2018. The research used a logistic regression as data analysis method with several statistical tests which included descriptive statistics, multicolinearity, fit test goodness, etc. The results show that only financial distress influences the acknowledgment of going concern audit opinion, while other independent variables such as debt default and disclosure do not affect the acceptance of going concern audit opinion. The research is limited since it only refers to the manufacturing industry sector. Therefore, it is suggested that future research expand the scope by obtaining more firms' sample from industrial sectors and using other independent variables to achieve a more accurate results.
\end{abstract}

Keywords: debt default, disclosure, financial distress, going concern audit opinion

\section{INTRODUCTION}

Each entity has a purpose in carrying out its activities, especially regarding the goal of going concerned. Companies are considered significant for the world's economy, which act as a provider of goods and services to society. Companies are required to maintain the continuity of their business in order to avoid bankruptcy. One of the foremost vital things in maintaining the company's business continuity is by presenting information about its condition through financial reports made by management regularly as a form of accountability to shareholders and interested parties (stakeholders).

Financial reports are increasingly reliable, and fairness can be trusted if they have gone through the audit process. The role of the auditor, in this case, is as an independent body that provides audit services, which ultimately can provide an opinion on the financial statements of a company. Besides, when the company's financial condition is dubious, speculators anticipate evaluators to allow an early caution of its monetary disappointment. Saputra and Kustina (2018) argue that the going concern audit opinion of an entity is one thing that underlies investors in making investment decisions and creditors in lending funds to obtain profits from the activities.

Going concern opinion is an explanation given by the auditor, where there is a noteworthy vulnerability or failure regarding the company's survival in the future (DeFond \& Zhang, 2014). To ascertain whether the company has a going concern, the auditor critically evaluates the planning carried out by management. In practice, going concern is a complicated matter so such factors are required as definite benchmarks to determine the company's going concern status.

In 2013 to 2018, PT Bakrie Sumatera Plantations Tbk (PT BSP) received a going concern opinion from KAPY Santosa and Partners. The acceptance of a going concern opinion by PT BSP is due to losses that are repeatedly experienced from business activities, which causes the total short-term consolidated liabilities to exceed the total current assets of the consolidated. Besides, in 2016 and 2017, PT BSP also experienced defaults based on specific loan agreements. In 2018, PT BSP has postponed the payment of specific loan principal and/or interest at maturity since the business group was restructuring its loans at that time. 
One of the aspects of assessing a company's viability is its failure to pay its debt obligations (debt default). According to Standard on Auditing (SA) 570 (2013), going concern assumption includes the company's failure to pay off its commitments to lenders concurring to the due date, and the failure to comply with the terms of the credit ascension causing questions around a substance. Chen and Church (1992) define debt default as the failure of the debtor (company) to pay its principal and/or interest at maturity. The debt default status may increase auditors' possibility to give an early warning by issuing a going concern opinion.

Disclosure of information by management is an essential factor for auditors in providing going concern opinion. Information regarding management's plans in overcoming company problems and resolutions will become the auditor's consideration before giving a going concern statement to the company. Johnstone, Gramling, and Rittenberg (2016) explain that the auditor's report includes basic financial statements, including balance sheets, income statements, cash flow statements, shareholder equity changes, and related notes. If the auditor determines that the informative disclosure is inadequate, the auditor will identify the fact in the audit report. In assessing the disclosures of financial statements, the auditor has confidence that events and transactions have occurred, and are related to the entity. All disclosures should be stated as included: 1) users of financial statements can understand disclosures; 2) information is disclosed accurately and appropriately.

The central aspect of predicting a company's viability is assessing its operating conditions, which are determined by the company's revenue. If there is a possible problem with the company's revenue, the prediction is that the company will not operate properly. Companies that are not operating well may indicate to be experiencing financial distress. Financial distress is a condition in which the company's money related condition amid a particular period comes about in negative net benefit, and the company's working cash stream is inadequate to progress.

Investors and creditors need to know their financial health condition when they want to make investment and credit decisions. Besides, as outsiders, they must know the company's development to secure the investment that has been made. Predictions of financial distress and bankruptcy can be analyzed from its financial statements by developing its financial ratio analysis (Ritonga \& Putri, 2019). However, in Indonesia, there are still few companies that realize the importance of this. Most companies restructure their companies both internally and externally after the bankruptcy. Not many company management has prevented the company from the risk of bankruptcy.

This consider proposes to reconfirm the components that influence the acknowledgment of going-concern audit opinion due to inconsistencies in previous research results. In the research, the sample used is a manufacturing company as one of the critical sectors and the largest contributor to establish national economic growth. Thus, the research objects are manufacturing companies listed on the Indonesia Stock Exchange in 2016-2018.

The research aims to: 1) determine the effect of going concern audit opinion acceptance of debt defaults in manufacturing companies; 2) determine the effect of disclosure on going concern audit opinion acceptance in manufacturing companies; and 3) identify financial distress's effect and acceptance of the audit opinion on going concerns in manufacturing companies.

Based on agency theory, the principal assesses the agent's performance using the auditor to determine the company's state. The first essential factor in measuring a company's financial health is examining company debt by an external auditor (Saputra \& Kustina, 2018). More abundant company's debt will lead the company to an operating losses, which affects its ability to fulfill its principal and interest obligations (Dewi \& Latrini, 2018). Suppose the company fails to pay its debt (debt default), in that case, the company's sustainability will be doubted. The possibility of giving a going concern audit opinion will be even more significant, and investment by outsiders will decrease (Harris \& Merianto, 2015). Based on the description, the following hypothesis can be formulated:

$\mathrm{H}_{1}$ : Debt Default has a positive and significant effect of ongoing concern audit opinion acceptance.

Based on agency theory in Jensen and Meckling (1976), the relationship between principals and agents leads to unbalanced information conditions since agents have more information about the company than principals. Harris and Merianto (2015) state that one of the principal's efforts to find out information is by having an auditor as a third party to disclose the company. Any accounting information in financial statements is often used as a basis for consideration by certain parties involved in the contract. The company's broader disclosure will provide additional evidence to the auditor to ensure that the company experiences survival problems to consider issuing a going concern audit opinion (Verdiana \& Utama, 2013). Based on this portrayal, the hypothesis can be defined:

$\mathrm{H}_{2}$ : Disclosure has a positive and significant effect of ongoing concern audit opinion acceptance.

Agency theory makes the auditor an independent third party in assessing management strategies to overcome financial distress (Jensen \& Merkling, 1976). Altman (1968) has conducted a research to find a prediction model for bankruptcy in the period before bankruptcy occurs. The prediction model used is based on the company's financial distress. Financial distress conditions indicate that the company is dealing with financial problems. If the Z-Score is low, it is more likely that the company will receive a going concern audit opinion. On the contrary, if the Z-Score is high or the company's financial condition is getting better, the 
auditor will less likely to issue a going concern audit opinion. Based on this description, the hypothesis can be formulated:

$\mathrm{H}_{3}$ : Financial distress has a negative and significant effect of ongoing concern audit opinion acceptance.

\section{METHODS}

The research takes a population of manufacturing firms listed on the Indonesia Stock Exchange (IDX) for the 2016-2018 period that publish audited financial reports. The type of data is quantitative with secondary data sources obtained from the Indonesia Stock Exchange's official website. The research sample uses a purposive sampling by determining five criteria, namely: 1) a manufacturing firm listed on the Indonesia Stock Exchange (IDX) and publishes complete audited financial reports during the observation period, i.e., 2016-2018; 2) excluding newly listed companies (IPO) on the Indonesia Stock Exchange during the observation period, i.e., 2016-2018; 3) manufacturing firms that were not out (delisted) from the IDX during the observation period, i.e., 2016-2018; 4) manufacturing firms that present their financial statements using the rupiah exchange rate Indonesian Rupiah (Rp); 5) manufacturing firms that experience negative current year net income for at least one period during the 2016-2018 observation year.

Data analysis uses a logistic regression. This method is used since going concern audit opinion as the dependent variable is dichotomous. Some of the statistical tests used are descriptive statistics, multicollinearity, fit test goodness, overall model fit, classification matrix, coefficient of determination, and hypothesis using logistic regression. Testing in the research is carried out using SPSS version 26.

\section{RESULTS AND DISCUSSIONS}

The population is manufacturing firms listed on the Indonesia Stock Exchange in 2016-2018. Due to the period of that year, there were many cases of giving going concern opinion on the company's financial statements. The test choice handle based on foreordained criteria is displayed in Table 1.

Descriptive statistical analysis provides an outline or portrayal of information appeared within the mean, standar deviation, maximum, and minimum value of each variable (Sugiyono, 2019).

Based on the descriptive-analytical test, it can be stated that the variable going concern audit opinion is measured based on the dummy variable. Of the 108 samples tested, the minimum value generated is 0 , which explains the firms that receive non-going concern audit opinion. The maximum value is 1 , which describes the companies that receive going concern audit opinion. The resulting average value for going-concern audit opinion acceptance is 0,19 , and a standard deviation is 0,390 . Next, the debt default variable is measured by a dummy variable,

Table 1 Sample Selection (Purposive Sampling)

\begin{tabular}{lcc}
\hline \multicolumn{1}{c}{ Criteria } & Total \\
\hline $\begin{array}{l}\text { A manufacturing firm listed on the Indonesia Stock Exchange (IDX) and publishes complete audited financial } \\
\text { reports amid the perception period, i.e., 2016-2018 }\end{array}$ & 168 \\
Newly listed companies (IPO) on the Indonesia Stock Exchange amid the perception period, i.e., $2016-2018$ & 25 \\
Manufacturing firms that were not out (delisted) from the IDX amid the perception period, i.e., 2016-2018 & 0 \\
Manufacturing firms that present their financial statements using the rupiah exchange rate (Rp) & $(30)$ \\
Manufacturing firms that experience negative current year net income for at least one period amid the 2016-2018 & 36 \\
the perception year
\end{tabular}

Source: Researcher

Table 2 Descriptive Statistics Test Results

\begin{tabular}{lccccc}
\hline & N & Min. & Max. & Mean & Std. Dev \\
\hline GCO & 108 & 0 & 1 & 0,19 & 0,390 \\
DD & 108 & 0 & 1 & 0,42 & 0,495 \\
DIS & 108 & 0,9 & 1,0 & 0,997 & 0,0165 \\
FD & 108 & $-10,65$ & 185,67 & 45,44 & $2.269,160$ \\
\hline
\end{tabular}

Note. GCO: Going Concern Opinion; DD: Debt Default; DIS: Disclosure; FD: Financial Distress Source: Output SPSS 26.0 
categorized based on the current ratio. The minimum value of the 108 samples tested is 0 . It means that the firm has no problem fulfilling its obligations. It is not categorized as a default status. It has a maximum value of 1 , which means that the company may have problems fulfilling its obligations to be categorized in default. This variable has an average value of 0,42 , which means that $42 \%$ of the 108 samples, namely 45 samples, are categorized as default, while the other 63 samples are not categorized as default status. The resulting standard deviation is 0,495 . Disclosure variables are measured using the scoring method with the disclosure index determined by the Otoritas Jasa Keuangan/OJK (Financial Services Authority of Indonesia). The company that had the least disclosure was Sunson Textile Manufacturer Tbk in 2016-2018, with information disclosure of $90 \%$. The disclosure variable that has been studied has an average of 0,997 out of 108 samples. It indicates that $99,7 \%$ of the samples have disclosed the information determined by the OJK. The resulting standard deviation value is 0,0165 . Finally, the financial distress variable is measured using the Altman Revised Z-Score ratio. Of the 108 samples tested, the minimum value produced is $-10,65$, Tiga Pilar Sejahtera Food Tbk's value in 2017. The maximum value is 185,67 , which is the value of Inti Agri Resources Tbk in 2017. Financial distress has an average value of 4,5444, which means that the average sample is in a safe area with a standard deviation value of 22,69160.

The multicollinearity test is conducted to detect any correlation between the independent variables in the regression model. Expressed free of multicollinearity refers to the tolerance value and Variance Inflation Factor (VIF). A tolerance value $\leq$ of 0,10 and VIF $\geq 10$ show that there is an indication of multicollinearity. A tolerance value $\geq$ of 0,10 and VIF $\leq 10$ represent no indication of multicollinearity.

Table 3 Multicollinearity Test

\begin{tabular}{llll}
\hline \multirow{2}{*}{ Model } & \multicolumn{2}{c}{ Collinearity Statistics } \\
\cline { 3 - 4 } & & Tolerance & VIF \\
\hline 1 & Debt Default & 0,963 & 1,039 \\
& Disclosure & 0,979 & 1,022 \\
& Financial Distress & 0,983 & 1,018 \\
\hline
\end{tabular}

Source: Output SPSS 26.0

Based on Table 3, each independent variable has a tolerance value $\leq 0,10$, debt default of 0,963 , disclosure of 0,979 , and financial distress of 0,983 . The test results show that the three independent variables are not correlated, so there is no multicollinearity in the regression model.

Furthermore, relating to the VIF value, the three independent variables are Debt Default of 1,039, disclosure of 1,022, and Financial Distress of 1,018.
The three independent variables have a VIF value of less than 10. Test results indicate that the three independent variables are not correlated, so there is no multicollinearity in the regression model.

The regression model's feasibility is assessed using the Hosmer and Lemeshow's Test to examine that the empirical data matched the model to be declared fit. The null hypothesis $\left(\mathrm{H}_{0}\right)$ is rejected if the Hosmer and Lemeshow's Test's significance level is equal to or less than 0,05 , which means a significant difference between the regression model and its observation value. The null hypothesis $\left(\mathrm{H}_{0}\right)$ is accepted on the antithesis if the Hosmer and Lemeshow's Test's significance level is more significant than 0,05 , meaning that the regression model can predict its observation value well.

Table 4 Goodness of Regression Model

\begin{tabular}{ccccc}
\hline \multicolumn{4}{c}{ Hosmer and Lemeshow Test } \\
\hline Step & 1 & Chi-square & df & Sig \\
& & 7,083 & 8 & 0,528 \\
\hline
\end{tabular}

Source: Output SPSS 26.0

Table 4 results from the regression model's feasibility test using the Hosmer and Lemeshow's Test table. It can be seen that the calculated Chi-Square value is 7,083 , with a significance value of 0,528 . Compared to the significance level of the model's feasibility test, 0,528 is more significant than $\alpha(0,05)$. From the results of these comparisons, it can be concluded that $\mathrm{H}_{0}$ is accepted, which means that the regression model is fit and can be interpreted.

Overall Model Fit is done by comparing the value between -2 Log-Likelihood (-2LL) at the beginning (Block Number $=0$ ) with the -2 LogLikelihood (-2LL) value at the end (Block Number $=$ 1). If there is a decrease in -2 Log-Likelihood or the -2 Log Likelihood value (Block Number $=0$ ) is more significant than -2 Log-Likelihood (Block Number $=$ 1), it means the whole model shows a good fit.

Table 5 Comparison of -2 Log-Likelihood (Block Number $=0)$ and -2 Log-Likelihood (Block Number $=1)$

\begin{tabular}{lc}
\hline & -2 Log-Likelihood \\
\hline Block 0 & 103.500 \\
Block 1 & 60.573 \\
\hline
\end{tabular}

Source: Output SPSS 26.0

Table 5 compares the -2 Log-Likelihood value $($ Block Number $=0$ ) with the -2 Log-Likelihood value (Block Number $=1)$. Table 5 shows that the regression model, which initially had a value of -2 Log-Likelihood 
103,500 decreases by 42,927 after inputting three independent variables to 60,573 . The test aims to test whether the hypothesized model is suitable or fit with the data or not. In the research, the decline in value that occurs shows that the fit model gets better after adding the model's independent variables.

The determination coefficient test aims to determine how much the combination of the independent variables, i.e., debt default, disclosure, and financial distress, can explain the dependent variable are going concern audit opinion.

Table 6 The Coefficient of Determination

\begin{tabular}{cccc}
\hline \multicolumn{4}{c}{ Model Summary } \\
\hline Step & -2 Log likelihood & $\begin{array}{c}\text { Cox \& Snell } \\
\text { R Squared }\end{array}$ & $\begin{array}{c}\text { Nagelkerke } \\
\text { R Squared }\end{array}$ \\
\hline 1 & $60,573^{\text {a }}$ & 0,328 & 0,532 \\
\hline
\end{tabular}

Note. a: estimation terminated at iteration number Source: Output SPSS 26.0

Table 6 shows that the -2 Log-Likelihood model test results in 60,573 of the coefficient of determination seen from the Nagelkerke R Squared of 0,532 (53,2\%) and the Cox \& Snell $\mathrm{R}$ Squared value of 0,328 $(32,8 \%)$. It means that the independent variable debt default, disclosure, and financial distress can explain the dependent variable's variation going concern audit opinion by $53,2 \%$. In comparison, other factors explain $46,8 \%$ of the dependent variable's variability outside of this research.

Table 7 Classification Matrix Test Results

\begin{tabular}{|c|c|c|c|c|c|}
\hline & & & \multicolumn{3}{|c|}{ Predicted } \\
\hline & & & \multicolumn{2}{|c|}{ GCO } & \multirow{2}{*}{$\%$ Correct } \\
\hline & & & NGCO & GCO & \\
\hline \multirow[t]{3}{*}{ Step 1} & GCO & NGCO & 86 & 2 & 97,7 \\
\hline & & $\mathrm{GCO}$ & 11 & 9 & 45,0 \\
\hline & $\begin{array}{l}\text { Overal } \\
\text { Percen }\end{array}$ & & & & 88,0 \\
\hline
\end{tabular}

Noted. GCO: Going Concern Opinion; NGCO: Non Going Concern Opinion

Source: Output SPSS 26.0

The classification matrix test aims to analyze the logistic regression model's accuracy in predicting the acceptance of going-concern audit opinion. Table 7 shows that the logistic regression model can predict $97,7 \%$ as a firm that does not receive a going concern audit opinion. Meanwhile, the nine sample data firms that receive going concern audit opinion state that the logistic regression model could predict $45 \%$ as firms that received going concern audit opinion. Overall, the regression model's predictive power can predict the probability of going concern audit opinion acceptance of $88 \%$.

The logistic regression test method is used to test the regression coefficient. Table 8 presents an overview of the logistic regression results.

Table 8 Testing using Logistic Regression

\begin{tabular}{llcc}
\hline & & B & Sig. \\
\hline Step 1 & Debt Default & 0,269 & 0,718 \\
& Disclosure & 147,823 & 0,999 \\
& Financial Distress & $-1,202$ & 0,000 \\
& Constant & $-148,931$ & 0,999 \\
\hline
\end{tabular}

Source: Output SPSS 26.0

The test outcomes on the regression coefficient produce the following logistic equation:

$\mathrm{OGC}=-148,931+0,269 \mathrm{DD}+147,823 \mathrm{D}-1,202$
$\mathrm{FD}$

Hypothesis testing is done using logistic regression to examine the correlation between the dependent variable, going concern audit opinion with the independent variables, i.e., debt default, disclosure, and financial distress. This test compares the value of the significance level of the logistic regression test results with the error rate $(\alpha)=5 \%$. Suppose the significant result is smaller than the error rate $(\operatorname{sig}<\alpha)$, then $\mathrm{H}_{0}$ is rejected since this variable is considered to have a significant effect $\left(\mathrm{H}_{\mathrm{a}}\right.$ accepted). Conversely, suppose the significant result is greater than the error rate $(\operatorname{sig}>\alpha)$, in that case, $\mathrm{H}_{0}$ is accepted because it can be concluded that the variable does not have a significant effect $\left(\mathrm{H}_{\mathrm{a}}\right.$ is rejected).

Based on Table 8 , each independent variable can be interpreted as affecting the acceptance of going-concern audit opinion. A constant of -148,931 means that if the independent variable's coefficient is ignored, the probability of a company receiving a going concern audit opinion will decrease by 148,931. The debt default variable shows a positive direction of 0,269 . However, since the significance value of the debt default variable is 0,718 and above $0,05(5 \%)$, it can be concluded that the debt default variable does not affect going concern audit opinion acceptance. Therefore, the $\mathrm{H}_{1}$ hypothesis is rejected.

Disclosure variable shows a positive direction of 147,823 . However, since the significance value of the disclosure variable is 0,999 and above $0,05(5 \%)$, it can be concluded that the disclosure variable does not affect going concern audit opinion acceptance. Therefore, the $\mathrm{H}_{2}$ hypothesis is rejected.

The financial distress variable shows a negative direction of 1,202 , with a significance value of the financial distress variable is 0,000 , below $0,05(5 \%)$. 
it can be concluded that the financial distress variable affects the acceptance of going concern audit opinion. Thus, the hypothesis $\mathrm{H}_{3}$ in the research is accepted.

Debt Default is a condition of a firm that fails to pay its principal debt and/or interest at maturity. In the research, debt default is proxied using dummy variables, categorized based on the value of the firm's current ratio. Based on the results of hypothesis testing in Table 8, it is known that the debt default variable shows a positive direction of 0,269 with a significance value of more than 0,05 , namely 0,718 . It can be concluded that this independent variable does not significantly affect going concern audit opinion acceptance, but has a positive influence on audit opinion acceptance. These results indicate that a firm with a debt default status or has failed to pay its maturing obligations and interest can increase the risk of doubts about business continuity and acceptance of going concern audit opinion.

The research results contradict research conducted by Harris and Merianto (2015), Dewi and Latrini (2018), and Read and Yezegel (2018). However, it is in line with Ritonga and Putri's research (2019) which affirms that debt default negatively affects going concern audit opinion acceptance.

When reviewing samples from 2016-2018 PT Jakarta Kyoei Steel Works Tbk and 2017 and 2018 PT Langgeng Makmur Industri Tbk, the two samples have a current ratio value of $\geq 1$. It is indicated that they do not experience debt default, but still receive an audit opinion going concerned. The research results do not prove that the debt default variable significantly affects accepting a going-concern audit opinion. Researchers argue that auditors providing a going concern audit opinion are not only based on debt defaults, but are more likely to see the company's ability to pay its general obligations.

Disclosure is the explanation on the acceptance of information by the company. Disclosure is measured using the scoring method with the annual report item disclosure index that the OJK has regulated. Based on the logistic regression testing results, the disclosure variable got a significance level of 0,999 and a coefficient of 147,823 , which illustrates that disclosure does not significantly affect going concern audit opinion, but has a positive effect on the going concern audit opinion acceptance.

The research results do not support research conducted by Harris and Merianto (2015), Achyarsyah (2016), Saputra and Kustina (2018), and Jamaluddin (2018). However, it supports Yaqin and Sari (2015) research, which states that disclosure does not affect the acceptance of going concern audit opinion, but has a negative effect on going concern audit opinion acceptance. The research explains how much disclosure will not make the company avoid giving going concern audit opinion. Excessive disclosure creates a wrong impression as the level of disclosure is too large.

The research has a disclosure average of $99,7 \%$, which describes the company's compliance in disclosing information. When viewed from the sample in 2016-2018, PT Sunson Textile Manufacturer Tbk has the lowest disclosure level, but does not accept going concern audit opinion. Meanwhile, companies that receives a going concern audit opinion included: 1) PT Tiga Pilar Sejahtera Food Tbk, 2) PT Central Proteina Prima Tbk, 3) PT Panasia Indo Resources Tbk, 4) PT Intikeramik Alamsari Industri Tbk, 5) PT Jakarta Kyoei Steel Works Tbk, 6) PT Kertas Basuki Rachmat Indonesia Tbk, 7) PT Langgeng Makmur Industri Tbk, and 8) PT Asia Pacific Investama Tbk, have an adequate level of disclosure. So that in this study, the disclosure variable does not have a significant effect on the acceptance of going-concern audit opinion.

Financial distress is an indication of a company's bankruptcy. In explaining the level of distress, this study uses the Altman Revised Z-Score model. Based on the results, hypothesis 3 declares that the financial distress variable affects the going concern audit opinion acceptance. Based on the results of hypothesis testing (see Table 8), it is known that the financial distress variable has a significance value of 0,000 which is lower than $\alpha$ and the variable coefficient value is $-1,202$. The regression results can be concluded that the financial distress variable has a significant negative effect on ongoing concern audit opinion acceptance. This negative effect means that the relationship between the Z-Score value and the acceptance of going concern audit opinion is inversely proportional. The smaller the Z-Score of the firm, the more likely the firm will be concerned about audit opinion and vice versa.

The research results are not in line with the research conducted by Listantri and Mudjiyanti (2016). However, the research is consistent with Achyarsyah (2016), Saputra and Kustina (2018), Dewi and Latrini (2018), Jamaluddin (2018), Read and Yezegel (2018), and Ritonga and Putri (2019) which state that that the financial distress variable has a negative and significant effect ongoing concern audit opinion acceptance. Ritonga and Putri (2019) state that a good firm condition indicates that the firm can continue its business in the future, so it is unlikely that the auditor will give a going concern audit opinion. On the other hand, a company whose financial condition is terrible indicates that the company is experiencing uncertainty in running its business in the future. It is more likely that the auditor will give a going concern audit opinion.

One of the variables reviewed from the sample, namely in 2017 PT Tiga Pilar Sejahtera Food Tbk has the lowest Z-Score value, namely -10,65. It is categorized into distress areas and received going concern audit opinion. Meanwhile, in 2017 PT Inti Agri Resources Tbk has the highest Z-Score, which is 185,67 , so it could be categorized into safe areas which do not accept going concern audit opinion.

Agency theory assumes that humans prioritize personal interests (self-interest). This causes agents not always to act according to the principals' wishes, so 
it may increase agency conflicts (Jensen \& Merkling, 1976). Agency conflicts that occur between agents and principals can be reduced by the presence of a third party, which is an independent auditor. Auditors can bridge the interests of agents and principals, especially in evaluating client business risks and assessing the feasibility of management strategies in overcoming financial distress, so this can reduce the acceptance of going concern audit opinion.

\section{CONCLUSIONS}

It can be concluded that the debt default and disclosure variables do not have a significant effect on ongoing concern audit opinion acceptance with a positive coefficient value. The financial distress variable has a significant negative effect on the ongoing concern audit opinion acceptance. Several implication can be concluded for investors to consider more about accepting going concern audit opinion from the auditor to the firm in making investment decisions. For business management, it is expected that they recognize signs of business bankruptcy early to immediately take policies to solve the problem and avoid receiving a going concern audit opinion. For the auditors, it is hoped that they will be able to develop further consideration of conditions that may affect the company's business continuity, both financial and nonfinancial conditions. The limitation of the research only refers to the manufacturing industry sector. Future research is expected to expand the research scope by increasing firms' sample from several industrial sectors, extending the research period, and using other independent variables such as non-financial ratios and other financial ratios. Therefore, research results are more accurate to continue growing.

\section{REFERENCES}

Achyarsyah, P. (2016). The analysis of the influence of financial distress, debt default, company size, and leverage ongoing concern opinion. International Journal of Applied Business and Economic Research, 14(10), 6767-6782. http://repository.unas.ac.id/id/ eprint $/ 62$.

Altman, E. I. (1968). Financial ratios, discriminant analysis and the prediction of corporate bankruptcy. The Journal of Finance, 23(4), 589-609. https://doi. org/10.2307/2978933.

Chen, K. C. \& Church, B. K. (1992). Default on debt obligation and the issuance of going-concern report. Auditing: A Journal of Practice and Theory, 11(2), 30-49.

DeFond, M. \& Zhang, J. (2014). A review of archival auditing research. Journal of Accounting \& Economics, 58(2), 275-326. https://doi. org/10.1016/j.jacceco.2014.09.002.

Dewi, D. A. N. S. \& Latrini, M. Y. (2018). Pengaruh financial distress dan debt default pada opini audit going concern. E-Jurnal Akuntansi, 22(2), 12231252. https://doi.org/10.24843/EJA.2018.v22.i02. p15.

Harris, R. \& Merianto, W. (2015). Pengaruh debt default, disclosure, opini audit tahun sebelumnya, ukuran perusahaan, dan opinion shopping terhadap penerimaan opini audit going concern, Diponegoro Journal of Accounting, 4(4), 298-308.

Jamaluddin, M. (2018). The effect of financial distress and disclosure on going concern opinion of the banking company listing in Indonesian Stock Exchange. International Journal of Scientific Research and Management, 6(1), 64-70. https://doi.org/10.18535/ ijsrm/v6il.em10.

Jensen, M. C and Meckling, W. H. (1976). Theory of the firm: Managerial behavior, agency costs and ownership structure. Journal of Financial Economics, $3(4), \quad 305-360$. https://doi.org/10.1016/0304405X(76)90026-X.

Johnstone, K. M., Gramling, A. A., \& Rittenberg, L. E. (2016). Auditing: A Risk-Based Approach to Conducting a Quality Audit (10 ${ }^{\text {th }}$ Ed.). Boston: Cengage Learning.

Listantri, F. \& Mudjiyanti, R. (2016). Analisis pengaruh financial distress, ukuran perusahaan, solvabilitas, dan profitabilitas terhadap penerimaan opini audit going concern. Jurnal Manajemen dan Bisnis Media Ekonomi, 16(1), 163-175.

Read, W. J. \& Yezegel, A. (2018). Advances in accounting going-concern opinion decisions on bankrupt clients: Evidence of long-lasting auditor conservatism ? Advances in Accounting, 40, 20-26. https://doi. org/10.1016/j.adiac.2017.12.004.

Ritonga, F. \& Putri, D. F. S. (2019). Debt default dan financial distress sebagai determinan penerimaan opini audit going concern. Jurnal Sains Manajemen \& Akuntansi, 11(1), 1-32. https://doi.org/10.37151/ jsma.v11i1.22.

Saputra, E. \& Kustina, K. T. (2018). Analisis pengaruh financial distress, debt default, kualitas auditor, auditor client tenure, opinion shopping dan disclosure, terhadap penerimaan opini audit going concern pada perusahaan manufaktur yang terdaftar di Bursa Efek Indonesia. KRISNA: Kumpulan Riset Akuntansi, 10(1), 1-10. https://doi.org/10.22225/ kr.10.1.\%25y.51-62.

Standard on Auditing (SA) 570 (Revised), Going Concern. (2013). http://kb.icai.org/pdfs/ PDFFile5b3b56f75d65b6.04883715.pdf

Sugiyono. (2019). Statistika untuk penelitian. Bandung: Alfabeta.

Verdiana, K. A. \& Utama, I. M. K. (2013). Pengaruh reputasi auditor, disclosure, audit client tenure pada kemungkinan pengungkapan opini audit going concern. E-Jurnal Akuntansi, 5(3), 530-543.

Yaqin, M. A. \& Sari, M. M. R. (2015). Pengaruh faktor keuangan dan non keuangan pada opini audit going concern. E-Jurnal Akuntansi, 11(2), 500-514. 